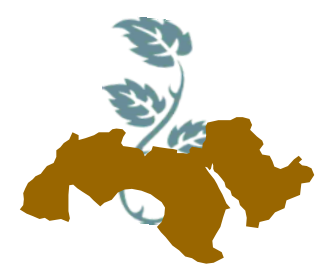

Arab Univ.

J. Agric. Sci., Ain Shams Univ., Cairo, 26(2), 491- 500, 2018

\title{
EFFECTS OF WATER SALINITY AND EGYPTIAN CLOVER AMENDED SUBSTRATES ON TOMATO TRANSPLANT PRODUCTION
}

\author{
Abu-Elela, A.R. ${ }^{1}$; K. Farrag ${ }^{1}$; U.A. El-Behairy ${ }^{2}$ and M.M.F. Abdallah ${ }^{2}$ \\ 1- Central Laboratory for Environmental Quality Monitoring (CLEQM), National Water Research \\ Center (NWRC), El-Kanater El-Kheria, Qalubiya, Egypt \\ 2- Horticulture Dept., Fac. of Agric., Ain Shams Univ., Cairo, Egypt
}

[37]

Keywords: Tomato transplants, clover amendments, fermentation, saline water

\section{ABSTRACT}

This study was conducted to evaluate the growth of tomato transplants irrigated with saline water in a commercial soilless potting media amended with fermented clover produced by anaerobic fermentation of a mixture of clover and water for different periods (1, 2 and 3 weeks). Treatments were distributed in completely randomized factorial design included three salinity levels in irrigation water (260, 1000 and $\left.2000 \mathrm{mg} \mathrm{l}^{-1}\right)$ without and with fermented clover corresponding to 0,10 , 20 and $30 \%$ of the substrate (1peat: 1perlite: 1 vermiculite) by volume. Plant height $(\mathrm{cm})$, number of leaves, vegetative fresh and dry weights $(\mathrm{g})$ per plant were recorded 35 days after sowing. The obtained results showed that the mean values of the aforementioned parameters were increased due to the incorporation of clover-based amendment with higher pronounced effect recorded for fermented clover as compared to non-fermented clover. The highest values were obtained due to the incorporation of three weeks fermented clover at $20 \%$ mixing percentage followed by $30 \%$. There were significant differences among water salinity treatments; fresh water $\left(260 \mathrm{mg} \mathrm{I}^{-1}\right)$ recorded the highest vegetative growth of tomato transplants. Furthermore, fermented clover alleviated the salt stress on transplants and increased the growth parameters under saline water irrigation. These results suggested that clover can be used for producing organic tomato transplants, instead of imported media, supporting by fermentation to enhance the ability of clover to supplement the trans- plants with the nutrient needs and cope the salinity condition.

\section{INTRODUCTION}

Due to the limited water resources in Egypt, farmers and producers are forced to manage the irrigation water carefully and improve their agricultural skills regarding water savings (Farrag et al 2016). Thus, use of irrigation water of certain salt content like ground water and treated wastewater for irrigating nursery plants is needed due to the limited supplies of fresh water in many countries; understanding how saline water can be used will also enhance sustainable development (Cassaniti et al 2013).

Tomato is the most important greenhouse vegetable crop grown in soilless cultivation systems in Mediterranean Basin, where it is often cultivated in saline or poor-quality irrigation water (Savvas et al., 2013). The most compromising effects of salinity on transplants production, specifically tomato, are reflected in inhibiting seed germination viability, generalized reduction of growth, loss of productive capacity and reductions in absorption of some essential nutrients (Cuartero \& Munoz, 1999; Maggio et al 2007; Hamed et al 2011 and Singh at al 2012).

Over the last decade an intensive study has been performed regarding the application of different agricultural, industrial and waste by-products as components of nursery substrates. The term 'substrate' is amongst others, i.e. growing medium, used to describe the material used in a container, other than soils, to grow a plant (Vaughn et al 2011). Growing substrates can include organic materials such as peat, compost, tree bark, coconut coir, poultry feathers, or inorganic materials 
such as clay, perlite, vermiculite, and mineral wool (Grunert et al 2008; Vaughn et al 2011 and Olle et al 2012) or mixes such as peat and perlite; coir and clay, peat and compost (Nair et al 2011 and Olle et al 2012). Plant response to different substrates is strictly related to the tested species and also depends on the materials used and on the proportions in the mixtures. However, addition of inorganic substances to organic ones has resulted in a better plant growth and higher yield probably owing to increasing water-holding capacity and aeration of peat (Olle et al 2012). With increase in demand for organically transplants, growers often design their mixes using compost and other organic amendments (Nair et al 2011). In particular, the emerged organic fertilizers and supplements in the market are usually expensive and not always locally available (Peet et al 2008).

Successfully, alfalfa-based amendment incorporated in compost-based medium produced tomato transplants with suitable growth characteristics and met acceptable standards for transplanting and handling, at a reasonable estimated production cost (Nair et al 2011). Therefore, the aim of the present work was to study the effect of fermented clover, as an amendment in growing media, on growth and development of tomato transplants grown organically under saline water irrigation.

\section{MATERIALS AND METHODS}

\section{Vegetal material and sowing}

The experiment was carried out at mesh nethouse of a commercial nursery with natural daylight conditions at El Qalyubiya Governorate, Egypt. Tomato seeds of cv. Castal rock var. ( $L y$ copersicom esculentum) were sown in $22^{\text {th }}$ September 2015 and grown for 35 days in foamed trays (dimensions: $65 \times 38 \times 8.3 \mathrm{~cm}$ ) with 209 cells, one seed being sowed per cell.

\section{Substrate components}

The growing media of this study were elaborated using fermented Egyptian clover (Trifolium alexandrinum L.) as organic substitutes for commercial soilless mixture of Peat/Perlite/vermiculite $(1: 1: 1 \mathrm{~V} / \mathrm{V} / \mathrm{V})$. Green clover was harvested in the mature stage from agricultural farm closed to the experimental location. The harvested clover was left for two weeks in shaded area till well dried and then it was chopped to small fractions $(2-3 \mathrm{~cm})$.
The fermentation process was performed by soaking the chopped fractions in fresh water $\left(260 \mathrm{mg} \mathrm{I}^{-}\right.$ $\left.{ }^{1}\right)$ for different periods (one, two and three weeks). After fermentation, the substrate is air-dried and sieved to $10 \mathrm{~mm}$ prior to be used as substrate component. Additional additives and/or fertilizers were not incorporated to the fermented clover. Fermented clover showed an acidic $\mathrm{pH}$ (5.39), low electrical conductivity (EC) values (1.18 dS $\mathrm{m}^{-1}$ ), organic matter content $\left(470 \mathrm{~g} \mathrm{~kg}^{-1}\right)$ and total Kjeldahl $\mathrm{N}$ contents $\left(28.5 \mathrm{~g} \mathrm{~kg}^{-1}\right)$.

\section{Formulation of growing media}

Different mixtures of fermented and nonfermented clover mixed with commercially used materials (peat moss, vermiculite and perlite) to obtain the substrates. The substrates were prepared prior to the experiment by substituting peat moss: vermiculite: perlite $(1: 1: 1 \mathrm{~V} / \mathrm{V} / \mathrm{V})$ with 0,10 , 20 and $30 \%$ of volume fermented and nonfermented clover, using pure peat moss, vermiculite and perlite as control treatment.

\section{Experimental design}

The experimental design was a completely randomized factorial design with three replications. Main treatments, sub-treatments and sub-subtreatments were assigned to fermentation duration, water salinity levels and different mixing percentages, respectively.

Treatments of fermentation duration consisted of four different durations (FO: control or dried clover without fermentation, F1: one week fermented clover, F2: two weeks fermented clover, F3: three weeks fermented clover) in the main treatments and three different water salinity levels (W0: control or fresh water $\left(260 \mathrm{mg} \mathrm{l}^{-1}\right), \mathrm{W} 1$ : saline water (1000 $\left.\mathrm{mg} \mathrm{l}^{-1}\right)$ and W2: saline water $\left(2000 \mathrm{mg} \mathrm{l}^{-1}\right)$ as subtreatments and four different mixing percentages (Q0: control or without clover, Q1, 10\% amended clover, Q2: 20\% amended clover and Q3: 30\% of amended clover) in subsub treatments were considered.

The treatments were irrigated daily according to the environmental conditions by hose with mist nozzle, using enough water to avoid stress in the cultivated transplants. The transplants were irrigated with different water salinity control (fresh water $260 \mathrm{mg} \mathrm{l}^{-1}$ ), 1000 and $2000 \mathrm{mg} \mathrm{l}^{-1}$. Water tanks $1 \mathrm{~m}^{3}$ were used for each water salinity treatment (control, 1000 and $2000 \mathrm{mg} \mathrm{I}^{-1}$ ). The salinity levels 
was done by using Rashidi salt (local salt extract from the Mediterranean Sea).

Compost tea as organic liquid fertilizer was applied twice a week for all the treatments. Compost tea extract were prepared by mixing mature compost (banana wastes $60 \%+$ cattle dung $30 \%+$ poultry manure $10 \%$ ) with tap water at a ratio of 1 : 2 (V/V), and storing this mixture at room temperature for about $24 \mathrm{~h}$ (Hegazi and Algharib, 2014). Aqueous extracts were freshly prepared and were filtered before applications with a hand sprayer. Also, an organic liquid fertilizer (Amino Power, UAD Company, Egypt) extracted from plant origin-pH: 12.50; EC: $65 \mathrm{dS} \mathrm{m}^{-1}$; organic carbon: $7 \%$; : $2.5 \mathrm{~g} \mathrm{I}^{-1}$, L-Amino acids 19\%, Fe $1500 \mathrm{mg} \mathrm{I}^{-}$

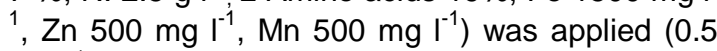
$\left.\mathrm{cm} \mathrm{I}^{-1}\right)$ thrice at the same rate for all the treatments at 10,20 and 30 days after sowing.

\section{Variables determined in the transplants}

Sex transplants were randomly chosen from the tray per treatment per replicate and harvested 35 days after sowing. Measurements of transplants height $(\mathrm{cm})$, number of leaves per plant, vegetative fresh and dry weight per plant $(\mathrm{g})$. Chlorophyll $a+b$ values in leaves of transplants were determined according to the procedure outlined by VonWettstein (1957).

\section{Statistical analysis}

Analysis of data was done by computer, using SAS program for statistical analysis (SAS, 2006). The experimental data were analyzed using three way analysis of variance with interactions. The Least significant difference test (LSD) at $5 \%$ level of probability was performed to compare the mean values and separate the groups.

\section{RESULTS AND DISCUSSIONS}

\section{Vegetative growth}

The results obtained in Tables (1-4) show the vegetative growth of tomato transplants including plant height, leaves number and fresh and dry weight of all treatments

\subsection{Vegetative growth}

The results obtained in Tables (1-4) show the vegetative growth of tomato transplants including plant height, leaves number and fresh and dry weight of all treatments.

Values of the pre-mentioned vegetative growth parameters of tomato transplants were gradually increased as the mixing percentage of clover, fermented and non-fermented, was sloping upward. The highest values were obtained due to the incorporation of $20 \%$ clover, fermented and nonfermented, followed by $30 \%$. The amendment type and rate for transplant media are key factors in determining the success of organic transplant production (Jack et al 2011). In this study, both fermented and non-fermented clover increased growth parameters of tomato transplants, with higher pronounced effect recorded for fermented clover based amendments as compared to nonfermented clover addition. Previous studies have confirmed that high rates of organic amendments can increased seedlings growth and yield (Gao et al 2010; Ismail et al 2011 and Olle et al 2012) in particular alfalfa based organic amendments (Nair et al 2011). In the evaluation of transplants, the better results obtained with incorporative clover are probably due to the higher nutrient supply, provided mainly by the fermented clover. The organic amendments are reported to increase the number of leaves per plants and lateral branches, plant height and dry weight of plants due to the nutritional needs of plants (Awodun et al 2015 and Rosenani et al 2016).

Furthermore, fermentation duration significantly increased these growth parameters compared with the non-fermented clover. Whereas, clover fermented for three weeks showed the highest values of tomato transplants growth parameters followed by two weeks of fermentation.

Fermented clover F1, F2 and F3, significantly increased means tomato transplants height to $10.86,10.76$ and $10.98 \mathrm{~cm}$, leaves number to 5.98 , 5.93 and 6.06 .98 , fresh weight to $4.66,4.76$ and $4.95 \mathrm{~g}$ and dry weight to $2.67,2.69$ and $2.82 \mathrm{~g}$ respectively, vis-à-vis non-fermented clover (F0), which produced $10.50 \mathrm{~cm}, 5.43,4.47 \mathrm{~g}$, and $2.47 \mathrm{~g}$, respectively, under fresh water irrigation (W0). A previous study investigated that growing medium of 2 peat: 1 vermiculite: 1 compost (by volume) when amended with $0,0.6,1.2,1.8$, or $2.4 \%$ weight by weight of alfalfa-based organic amendment and incubated for $0,1,2,3$, or 4 weeks had increased transplant height, leaf chlorophyll content and plant dry weight ( $90 \%$ to $160 \%$ more), provided the amended medium was incubated for at least one week (Nair et al 2011). 
Table 1. Effects of fermented and non-fermented clover rate $(0,10,20,30 \%)$ in peat-vermiculite-perlite $(1: 1: 1 \mathrm{~V} / \mathrm{V} / \mathrm{V})$ growing medium on tomato transplants height $(\mathrm{cm}) 35$ days after sowing using fresh and saline $\left(1000,2000 \mathrm{mg} \mathrm{l}^{-1}\right)$ water irrigation.

\begin{tabular}{|c|c|c|c|c|c|c|}
\hline \multirow{3}{*}{ Fermentation (F) } & \multirow{3}{*}{$\begin{array}{c}\text { Water Salinity } \\
\text { (W) } \\
\mathrm{mg} \mathrm{l}^{-1} \\
\end{array}$} & \multicolumn{4}{|c|}{ Clover mixing percentage $(Q)$} & \multirow{3}{*}{ Mean } \\
\hline & & $0(\mathbf{Q 0})$ & $10(Q 1)$ & 20 (Q2) & $30($ Q3) & \\
\hline & & \multicolumn{4}{|c|}{$\%$} & \\
\hline \multirow{4}{*}{ No fermentation (F0) } & FW (W0) & 9.42 & 10.57 & 11.18 & 10.84 & 10.50 \\
\hline & $1000(\mathrm{~W} 1)$ & 6.87 & 7.92 & 8.37 & 7.99 & 7.79 \\
\hline & 2000 (W2) & 6.19 & 7.12 & 7.60 & 7.33 & 7.06 \\
\hline & Mean & 7.49 & 8.54 & 9.05 & 8.72 & 8.45 \\
\hline \multirow{4}{*}{ Fermentation 1 week (F1) } & FW (W0) & 9.61 & 11.16 & 11.50 & 11.18 & 10.86 \\
\hline & 1000 (W1) & 7.22 & 8.54 & 9.21 & 8.82 & 8.45 \\
\hline & 2000 (W2) & 6.45 & 7.98 & 8.42 & 8.13 & 7.74 \\
\hline & Mean & 7.76 & 9.23 & 9.71 & 9.38 & 9.02 \\
\hline \multirow{4}{*}{ Fermentation 2 week (F2) } & FW (W0) & 9.54 & 10.88 & 11.47 & 11.15 & 10.76 \\
\hline & $1000(\mathrm{~W} 1)$ & 7.38 & 9.08 & 9.58 & 9.26 & 8.82 \\
\hline & 2000 (W2) & 6.50 & 8.23 & 8.71 & 8.40 & 7.96 \\
\hline & Mean & 7.81 & 9.40 & 9.92 & 9.60 & 9.18 \\
\hline \multirow{4}{*}{ Fermentation 3 week (F3) } & FW (W0) & 9.62 & 11.25 & 11.82 & 11.24 & 10.98 \\
\hline & 1000 (W1) & 7.24 & 9.48 & 10.10 & 9.64 & 9.12 \\
\hline & 2000 (W2) & 6.52 & 8.66 & 9.11 & 8.76 & 8.26 \\
\hline & Mean & 7.79 & 9.80 & 10.34 & 9.88 & 9.45 \\
\hline \multirow{4}{*}{ Interaction } & $\mathrm{FW}(\mathrm{W} 0)$ & 10.50 & 10.86 & 10.76 & 10.98 & 10.78 \\
\hline & $1000(\mathrm{~W} 1)$ & 7.79 & 8.45 & 8.82 & 9.12 & 8.54 \\
\hline & 2000 (W2) & 7.06 & 7.74 & 7.96 & 8.26 & 7.76 \\
\hline & Mean & 8.45 & 9.02 & 9.18 & 9.45 & 9.03 \\
\hline \multicolumn{7}{|c|}{ Least significant difference test (LSD) at $5 \%$} \\
\hline$F$ & Q & W & $F \times Q$ & $\mathrm{~F} \times \mathrm{W}$ & $Q \times W$ & $F \times Q \times W$ \\
\hline 0.05 & 0.05 & 0.04 & 0.09 & 0.14 & NS & 0.16 \\
\hline
\end{tabular}

Table 2. Effects of fermented and non-fermented clover rate $(0,10,20,30 \%)$ in peat-vermiculite-perlite $(1: 1: 1 \mathrm{~V} / \mathrm{V} / \mathrm{V})$ growing medium on tomato transplants leaves numbers 35 days after sowing using fresh and saline $\left(1000,2000 \mathrm{mg} \mathrm{l}^{-1}\right)$ water irrigation.

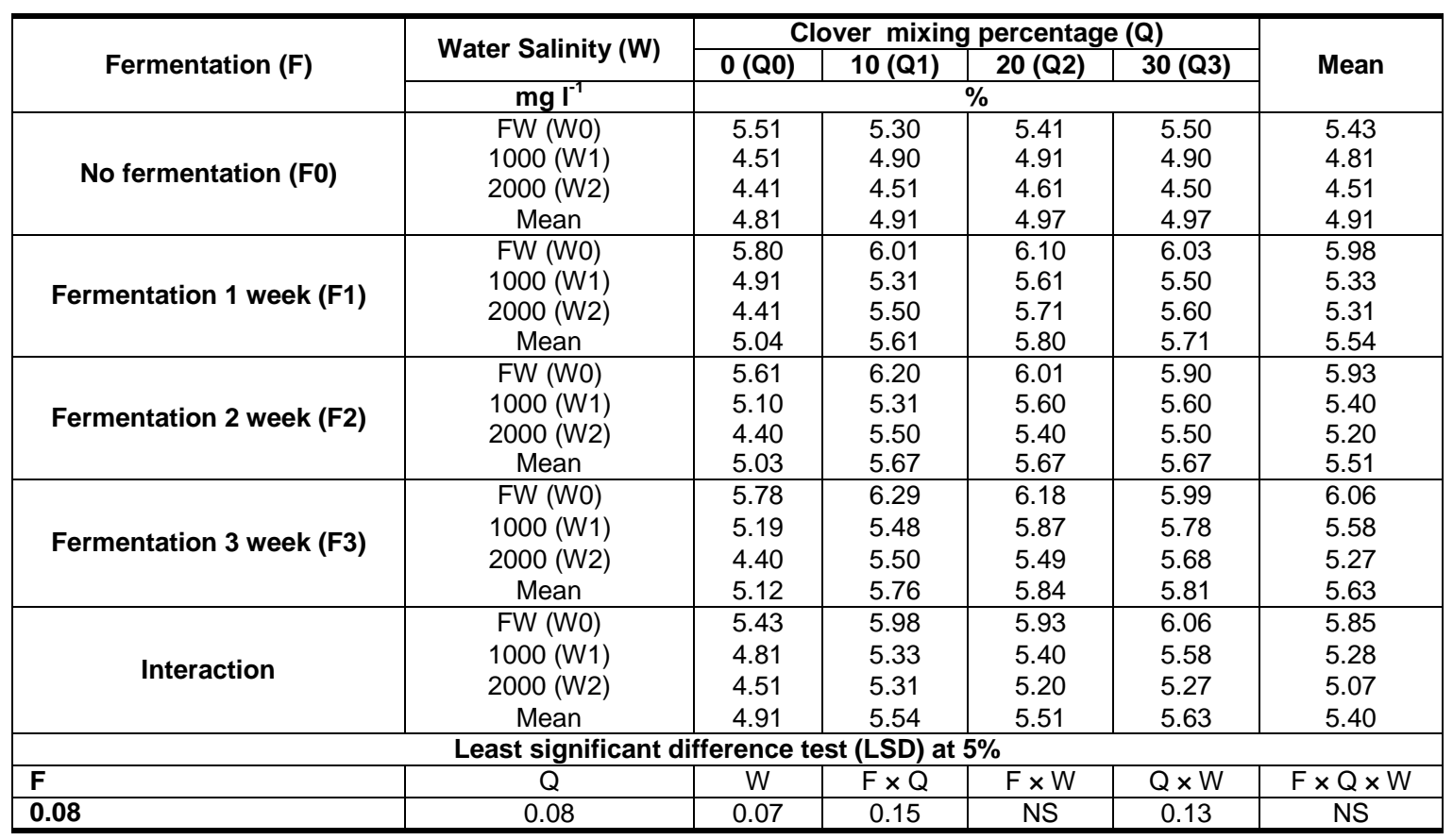



transplant production

Table 3. Effects of fermented and non-fermented clover rate $(0,10,20,30 \%)$ in peat-vermiculite-perlite $(1: 1: 1 \mathrm{~V} / \mathrm{V} / \mathrm{V})$ growing medium on tomato transplants fresh weight $(\mathrm{g}) 35$ days after sowing using fresh and saline $\left(1000,2000 \mathrm{mg} \mathrm{l}^{-1}\right)$ water irrigation.

\begin{tabular}{|c|c|c|c|c|c|c|}
\hline \multirow{3}{*}{ Fermentation (F) } & \multirow{2}{*}{ Water Salinity (W) } & \multicolumn{4}{|c|}{ Clover mixing percentage $(Q)$} & \multirow{3}{*}{ Mean } \\
\hline & & $0(\mathbf{Q 0})$ & 10 (Q1) & 20 (Q2) & 30 (Q3) & \\
\hline & mg l-1 & \multicolumn{4}{|c|}{$\%$} & \\
\hline \multirow{6}{*}{ No fermentation (F0) } & FW (W0) & 4.50 & 4.32 & 4.63 & 4.43 & 4.47 \\
\hline & 1000 (W1) & 3.12 & 3.34 & 3.58 & 3.36 & 3.35 \\
\hline & 2000 (W2) & 2.09 & 2.54 & 2.88 & 2.78 & 2.57 \\
\hline & Mean & 3.23 & 3.40 & 3.70 & 3.52 & 3.46 \\
\hline & FW (W0) & 4.50 & 4.77 & 4.63 & 4.73 & 4.66 \\
\hline & 1000 (W1) & 4.23 & 4.61 & 4.42 & 1.28 & 3.64 \\
\hline \multirow{3}{*}{ Fermentation 1 week (F1) } & 2000 (W2) & 2.17 & 3.59 & 2.88 & 3.63 & 3.07 \\
\hline & Mean & 3.63 & 4.32 & 3.98 & 3.21 & 3.79 \\
\hline & FW (W0) & 4.44 & 4.85 & 5.13 & 4.62 & 4.76 \\
\hline \multirow{4}{*}{ Fermentation 2 week (F2) } & 1000 (W1) & 3.33 & 4.66 & 4.70 & 4.61 & 4.33 \\
\hline & 2000 (W2) & 2.19 & 3.73 & 3.96 & 3.80 & 3.42 \\
\hline & Mean & 3.32 & 4.41 & 4.60 & 4.35 & 4.17 \\
\hline & FW (W0) & 4.45 & 5.08 & 5.45 & 4.80 & 4.95 \\
\hline \multirow{3}{*}{ Fermentation 3 week (F3) } & 1000 (W1) & 3.32 & 4.89 & 5.09 & 4.95 & 4.56 \\
\hline & 2000 (W2) & 2.12 & 4.05 & 4.25 & 4.06 & 3.62 \\
\hline & Mean & 3.30 & 4.68 & 4.93 & 4.60 & 4.38 \\
\hline \multirow{4}{*}{ Interaction } & FW (W0) & 4.47 & 4.66 & 4.76 & 4.95 & 4.71 \\
\hline & 1000 (W1) & 3.35 & 3.64 & 4.33 & 4.56 & 3.97 \\
\hline & 2000 (W2) & 2.57 & 3.07 & 3.42 & 3.62 & 3.17 \\
\hline & Mean & 3.46 & 3.79 & 4.17 & 4.38 & 3.95 \\
\hline \multicolumn{7}{|c|}{ Least significant difference test (LSD) at $5 \%$} \\
\hline $\mathbf{F}$ & $Q$ & W & $F \times Q$ & $\mathrm{~F} \times \mathrm{W}$ & $\mathrm{Q} \times \mathrm{W}$ & $\mathrm{F} \times \mathrm{Q} \times \mathrm{W}$ \\
\hline 0.08 & 0.08 & 0.07 & 0.15 & 0.13 & 0.13 & NS \\
\hline
\end{tabular}

Table 4. Effects of fermented and non-fermented clover rate $(0,10,20,30 \%)$ in peat-vermiculite-perlite $(1: 1: 1 \mathrm{~V} / \mathrm{V} / \mathrm{V})$ growing medium on tomato transplants dry weight $(\mathrm{g}) 35$ days after sowing using fresh and saline $\left(1000,2000 \mathrm{mg} \mathrm{l}^{-1}\right)$ water irrigation.

\begin{tabular}{|c|c|c|c|c|c|c|}
\hline \multirow{3}{*}{ Fermentation (F) } & \multirow{2}{*}{$\begin{array}{l}\text { Water Salinity } \\
\text { (W) }\end{array}$} & \multicolumn{4}{|c|}{ Clover mixing percentage (Q) } & \multirow{3}{*}{ Mean } \\
\hline & & $0(Q 0)$ & $10(Q 1)$ & 20 (Q2) & $30(Q 3)$ & \\
\hline & $\mathrm{mg} \mathrm{l}^{-1}$ & \multicolumn{4}{|c|}{$\%$} & \\
\hline \multirow{4}{*}{ No fermentation (F0) } & FW (W0) & 2.52 & 2.44 & 2.53 & 2.40 & 2.47 \\
\hline & $1000(\mathrm{~W} 1)$ & 1.76 & 1.88 & 1.99 & 1.90 & 1.88 \\
\hline & 2000 (W2) & 1.27 & 1.47 & 1.64 & 1.59 & 1.49 \\
\hline & Mean & 1.85 & 1.93 & 2.05 & 1.96 & 1.95 \\
\hline \multirow{4}{*}{$\begin{array}{l}\text { Fermentation } 1 \text { week } \\
\text { (F1) }\end{array}$} & FW (W0) & 2.54 & 2.61 & 2.88 & 2.66 & 2.67 \\
\hline & $1000(\mathrm{~W} 1)$ & 1.84 & 2.35 & 2.54 & 2.39 & 2.28 \\
\hline & 2000 (W2) & 1.35 & 2.02 & 2.09 & 2.03 & 1.87 \\
\hline & Mean & 1.91 & 2.33 & 2.50 & 2.36 & 2.27 \\
\hline \multirow{4}{*}{$\begin{array}{l}\text { Fermentation } 2 \text { week } \\
\text { (F2) }\end{array}$} & FW (W0) & 2.48 & 2.73 & 2.91 & 2.64 & 2.69 \\
\hline & 1000 (W1) & 1.86 & 2.61 & 2.61 & 2.58 & 2.41 \\
\hline & 2000 (W2) & 1.28 & 2.07 & 2.21 & 2.13 & 1.92 \\
\hline & Mean & 1.87 & 2.47 & 2.58 & 2.45 & 2.34 \\
\hline \multirow{4}{*}{$\begin{array}{l}\text { Fermentation } 3 \text { week } \\
\text { (F3) }\end{array}$} & FW (W0) & 2.49 & 2.88 & 3.15 & 2.77 & 2.82 \\
\hline & 1000 (W1) & 1.85 & 2.82 & 2.91 & 2.84 & 2.60 \\
\hline & 2000 (W2) & 1.32 & 2.38 & 2.52 & 2.39 & 2.15 \\
\hline & Mean & 1.89 & 2.69 & 2.86 & 2.67 & 2.53 \\
\hline \multirow{4}{*}{ Interaction } & FW (W0) & 2.47 & 2.67 & 2.69 & 2.82 & 2.67 \\
\hline & $1000(\mathrm{~W} 1)$ & 1.88 & 2.28 & 2.41 & 2.60 & 2.29 \\
\hline & 2000 (W2) & 1.49 & 1.87 & 1.92 & 2.15 & 1.86 \\
\hline & Mean & 1.95 & 2.27 & 2.34 & 2.53 & 2.27 \\
\hline \multicolumn{7}{|c|}{ Least significant difference test (LSD) at $5 \%$} \\
\hline $\mathbf{F}$ & Q & W & $F \times Q$ & $\mathrm{~F} \times \mathrm{W}$ & $Q \times W$ & $F \times Q \times W$ \\
\hline 0.07 & 0.07 & 0.06 & 0.13 & 0.11 & 0.11 & NS \\
\hline
\end{tabular}


On contrary, the vegetative growth parameters of tomato transplants gradually decreased as the water salinity levels increased. The negative effects of salinity have been reported on growth and production of tomato (Salama et al 2012). In general, three major stresses affecting plant growth under salinity: (i) osmotic stress (ii) nutritional imbalances, and (iii) ion toxicity, e.g. $\mathrm{Na}^{+}$(Grattan \& Grieve, 1998; Carvajal et al 1999 and Wahome et al 2001).

However, plants grown in fermented clover F1, F2 and F3 and irrigated with saline water at 1000 $\mathrm{mg} \mathrm{l}^{-1}$ (W1) showed significant reduction in the tomato transplants height $(22.2,18,16.9 \%)$, number of leaves $(10.9,8.9,7.9 \%)$ and fresh $(21.9,9$, $7.9 \%)$ and dry $(14.6,10.4,7.8 \%)$ weight, respectively, compared with non-fermented clover F0 $(25.8,11.4,25.1,23.9 \%)$ irrigated with fresh water (W0). Whereas irrigated plants grown in fermented clover F1, F2 and F3 with saline water at $2000 \mathrm{mgl}^{-}$ 1 (W2) decreased the height $(28.7,26,24.8 \%)$, number of leaves $(11,12.3,13 \%)$ and fresh $(34.1$, $28.2,26.9 \%)$ and dry $(30,28.6,23.8 \%)$ weight, respectively, compared with non-fermented clover F0 (32.8, 16.9,42.5, 39.7\%) irrigated with fresh water (W0). Gupta and Huang (2014) mentioned that salt stress causes changes in several physiological and metabolic processes, inhibiting seedlings growth and crop production. In addition, salt stress initially causes stomatal closure and increased leaf temperature, which results in loss of growth, leaf expansion and quality of seedlings (Roy et al 2014).

It is noteworthy that incorporation of growing media of tomato transplants irrigated with saline water with fermented clover alleviated the salt stress on plants and increased the growth parameters (Tables 2-5). Whereas, growing media incorporation with fermented clover F1, F2 and F3 resulted in significantly higher means of both transplants height for $8.5,13.2$ and $17.1 \%$, leaves number for $10.8,12.3$ and $16 \%$, fresh weight for 8.7 , 29.3 and $36.1 \%$ and dry weight for $21.3,28.2$ and $38.3 \%$, respectively, under $1000 \mathrm{mg} \mathrm{I}^{-1}$ saline water (W1) irrigation than under non-fermented clover (F0).

Similarly, fermented clover incorporated medium (F1, F2 and F3) with the saline water $2000 \mathrm{mg}$ $\mathrm{I}^{-1}$ (W2) irrigation significantly increased transplants height for 9.6, 12.7 and $17 \%$, leaves number for 17 . 7, 15.3 and $16.9 \%$, fresh weight for $19.5,33.1$ and $40.9 \%$ and dry weight for $25.5,28.9$ and $44.3 \%$, respectively, compared with non-fermented clover incorporated medium (F0). For both salinity levels of irrigation water, the highest growth parameters were obtained from the combination of growing medium with $20 \%$ (Q2) addition of three weeks fermented clover. Silva et al (2008) reported that organic compounds both in solid form such as organic matter and in liquid form such as some biofertilizers can attenuate deleterious effects of irrigation water salinity during the formation seedlings. Biofertilizers, when applied, stimulate growth, photosynthetic rate, stomatal conductance and plant transpiration even under saline conditions (Mesquita et al 2014).

\subsection{Chemical constituents}

\subsubsection{Chlorophyll $a+b$ content}

From the given data in Table (5) it can be concluded that, increasing clover mixing rates and fermentation duration caused significant increase in the content of chlorophyll $a+b$. Accordingly it can be stated that incorporation of growing medium with $20 \%(\mathrm{Q} 2)$ and $30 \%(\mathrm{Q} 3)$ of clover fermented for two or three weeks duration was the most effective treatment for promoting the synthesis and accumulation of the photosynthetic pigments. These results were in harmony with those obtained by Nair et al (2011), who showed that incorporating alfalfa based amendments in a peat-compost medium increased leaf content of chlorophyll in organic tomato transplants. Several factors are affecting leaf chlorophyll content, including nutrient concentration, $\mathrm{N}$ in particular, distribution of chlorophyll in leaves and plant genotype (Wang et al 2004 and Uddling et al 2007).

Transplants grown in two weeks fermented clover (F2) and irrigated with fresh water (W0) produced the greatest content $\left(2.36 \mathrm{mg} \mathrm{l}^{-1}\right)$ of chlorophyll $\mathrm{a}+\mathrm{b}$, whereas the lowest content $\left(1.20 \mathrm{mg} \mathrm{l}^{-1}\right)$ was recorded in tomato transplants grown in nonamended medium and irrigated with saline water W2 (2000 mg l-1). Saline water irrigation tended to decrease chlorophyll $a+b$ content as comparing with the fresh water treatments in both incorporated fermented and non-fermented clover media. Salinity changes the metabolism and physiology of plants, with negative effects on the photosynthetic capacity and chlorophyll accumulation (Souto et al 2015).

Furthermore, growing media incorporation with fermented clover at different duration resulted in significantly higher content of chlorophyll $a+b$ under saline water irrigation compared with nonfermented clover incorporated medium. 
Table 5. Effects fermented and non-fermented clover rate $(0,10,20,30 \%)$ in peat-vermiculite-perlite $(1: 1: 1$ V/V/V) growing medium on tomato transplants chlorophyll $\mathrm{a}+\mathrm{b}$ content $\left(\mathrm{mg} \mathrm{l}^{-1}\right) 35$ days after sowing using fresh and saline $\left(1000,2000 \mathrm{mg} \mathrm{l}^{-1}\right)$ water irrigation

\begin{tabular}{|c|c|c|c|c|c|c|}
\hline \multirow{3}{*}{ Fermentation (F) } & \multirow{2}{*}{ Water Salinity (W) } & \multicolumn{4}{|c|}{ Clover mixing percentage (Q) } & \multirow{3}{*}{ Mean } \\
\hline & & $0(Q 0)$ & 10 (Q1) & 20 (Q2) & $30(\mathrm{Q3})$ & \\
\hline & $\mathrm{mg} \mathrm{l}^{-1}$ & \multicolumn{4}{|c|}{$\%$} & \\
\hline \multirow{4}{*}{ No fermentation (F0) } & $\mathrm{FW}(\mathrm{W} 0)$ & 2.00 & 1.79 & 1.99 & 1.88 & 1.92 \\
\hline & $1000(\mathrm{~W} 1)$ & 1.54 & 1.56 & 1.64 & 1.58 & 1.58 \\
\hline & 2000 (W2) & 1.28 & 1.40 & 1.49 & 1.47 & 1.41 \\
\hline & Mean & 1.61 & 1.58 & 1.71 & 1.65 & 1.64 \\
\hline \multirow{4}{*}{ Fermentation 1 week (F1) } & FW (W0) & 2.03 & 2.05 & 2.14 & 1.99 & 2.05 \\
\hline & 1000 (W1) & 1.52 & 1.92 & 1.93 & 1.88 & 1.81 \\
\hline & 2000 (W2) & 1.20 & 1.62 & 1.70 & 1.67 & 1.55 \\
\hline & Mean & 1.58 & 1.86 & 1.93 & 1.85 & 1.80 \\
\hline \multirow{4}{*}{ Fermentation 2 week (F2) } & FW (W0) & 1.97 & 2.33 & 2.36 & 2.28 & 2.23 \\
\hline & $1000(\mathrm{~W} 1)$ & 1.58 & 1.96 & 2.06 & 1.97 & 1.89 \\
\hline & 2000 (W2) & 1.23 & 1.80 & 1.86 & 1.82 & 1.68 \\
\hline & Mean & 1.59 & 2.03 & 2.09 & 2.02 & 1.93 \\
\hline \multirow{4}{*}{ Fermentation 3 week (F3) } & FW (W0) & 2.00 & 2.21 & 2.32 & 2.10 & 2.16 \\
\hline & 1000 (W1) & 1.53 & 2.04 & 2.11 & 2.06 & 1.93 \\
\hline & 2000 (W2) & 1.24 & 1.82 & 1.87 & 1.82 & 1.69 \\
\hline & Mean & 1.59 & 2.02 & 2.10 & 1.99 & 1.93 \\
\hline \multirow{4}{*}{ Interaction } & FW (W0) & 1.92 & 2.05 & 2.23 & 2.16 & 2.09 \\
\hline & 1000 (W1) & 1.58 & 1.81 & 1.89 & 1.93 & 1.81 \\
\hline & 2000 (W2) & 1.41 & 1.55 & 1.68 & 1.69 & 1.58 \\
\hline & Mean & 1.64 & 1.80 & 1.93 & 1.93 & 1.83 \\
\hline \multicolumn{7}{|c|}{ Least significant difference test (LSD) at $5 \%$} \\
\hline $\mathbf{F}$ & $\mathrm{Q}$ & W & $\mathrm{F} \times \mathrm{Q}$ & $\mathrm{F} \times \mathrm{W}$ & $Q \times W$ & $F \times Q \times W$ \\
\hline 0.04 & 0.04 & 0.03 & 0.08 & NS & 0.07 & NS \\
\hline
\end{tabular}

The incorporation of clover may have provided the release of liquid or solid humic substances to the substrate which stimulate the osmotic adjustment of plants growing in a saline environment (Brahmaprakash and Sahu, 2012).

\section{CONCLUSION}

It could be concluded that vegetative growth of tomato transplants significantly increase due to incorporation of fermented clover with commercial growing media using saline irrigation water reveal the possibility for creating synergy among agronomic practices. This implies that an entire package of agronomic practices will have to be considered to transform nursery practices of transplants growing into sustainable greenhouse production that use much less commercial growing substrates and fresh water.

\section{ACKNOWLEDGEMENTS}

This research has been supported by the Central Laboratory for Environmental Quality Monitoring (CLEQM), National Water Research Center (NWRC), Cairo, Egypt.

\section{REFERENCES}

Awodun, M.A., Osundare, O.T., Oyelekan, S.A. and Okonji C.J., 2015. Comparative effects of organic and inorganic soil amendments on the growth of cashew nut (Anacardium occidentale L.) seedlings. J. Agric. Biotech. Sustain. Dev., 7(4), 37-42.

Brahmaprakash, G.P. and Sahu, P.K., 2012. Biofertilizers for sustainability. J. India Inst. Sci. 92, 37-62.

Carvajal, M., Martinez, V. and Alcaraz, C., 1999. Physiological function of water channels as affected by salinity in roots of paprika pepper. Physiologia Plantarum, 105, 95-101.

Cassaniti, C., Romano, D., Hop, M.E.C.M. and Flowers, T.J., 2013. Growing floricultural crops with brackish water. Environ. Exp. Bot. 92, 165-175.

Cuartero, J. and Munoz, R.F., 1999. Tomato and salinity. Scientia Horticulture, 78, 83-125.

Dada, O.A. and Fayinminnu, 0.0., 2010. Period of weed control in Okra (Abelmoschus esculentus (L.) Moench) as influenced by varying rates of cattle dung and weeding regimes. Not. Bot. Hort. Agrobot. Cluj, 38, 149-154. 
Farrag, K., Abdrabbo, M.A.A. and Hegab, S.A.M., 2016. Growth and productivity of potato under different irrigation levels and mulch types in the North West of the Nile Delta, Egypt. Middle East J. Appl. Sci., 6(4),774-786

Gao, H.B., Zhang, T. J., Lv, G. Y., Zhang, G. H., Wu, X. L., Li, J. R. and Gong, B.B., 2010. Effects of different compound substrates on growth, yield and fruit quality of cucumber, Acta Horticulturae, 856, 173-180.

Grattan, S. and Grieve, C., 1998. Salinity-mineral nutrient relations in horticultural crops. Scientia Horticulture, 78, 127-157.

Grunert, O., Perneel, M. and Vandaele, S., 2008. Peat-based organic grow bags as a solution to the mineral wool waste problem. Mires and Peat, 3, 1-5

Gupta, B. and Huang, B., 2014. Mechanism of salinity tolerance in plants: Physiological, biochemical, and molecular characterization. Int. J. of Genomics, pp. 1-18.

Hamed, K., Hossein, N., Mohammad, F., Safieh, V.J., 2011. How salinity affect germination and emergence of tomato lines. J. Biol. Environ. Sci. 5(15), 159-163.

Hegazi, A.Z. and Algharib A.M., 2014. Utilizing compost tea as a nutrient amendment in open filed cowpea seed production system. J. Bio. Env. Sci. 5(2) 318-328.

Ismail, A.M, D'Onghia, A.M. and Nigro, F., 2011. Influence of organic growing media in combination with microbial bioagents (Clonotri or Sublic) on the growth parameters of olive (Olea europaea L.) plantlets in the nursery. Agric. Biol. J. Nutr. American, 2(5), 767-772

Jack, A.L.H., Rangarajan, A., Culman, S.W. Sooksa-Nguan, T. and Thies, J.E., 2011. Choice of organic amendments in tomato transplants has lasting effects on bacterial rhizosphere communities and crop performance in the field. Appl. Soil Ecol. 48(1), 94-101.

Maggio, A., Raimondi, G., Martinoi, A. and DeParcale, S., 2007. Salt stress response in tomato beyond the salinity tolerance threshold. Environ. Exp. Bot. 59(3), 276-281.

Mesquita, S.B.S., Silva, J.A., Costa, R.S., Santos, M.W.N., Lacerda, C.F., Amorim, A.V. and Bezerra, A.M.E., 2014. Gas Exchange and Growth of Medicinal Plant Subjected to Salinity and Application of Biofertilizers. Am. J. Plant Sci. 5, 2520-2527.

Nair, A., Ngouajio, M. and Biernbaum, J., 2011. Alfalfa-based organic amendment in peatcompost growing medium for organic tomato transplant production. HortScience, 46, 253259.

Olle, M., Ngouajio, M. and Siomos, A., 2012. Vegetable quality and productivity as influenced by growing medium: a review. Žemdirbystè Agriculture, 99 (4), 399-408.

Peet, M.M., Larrea, E.S. and Harlow, C., 2008. Tomato seed germination in organic mixes: Role of EC and mix components. Acta Hort. 797, 393-398.

Rosenani, A.B., Rovica, R., Cheah, P.M., Lim, C.T., 2016. Growth performance and nutrient uptake of oil palm seedling in prenursery stage as influenced by oil palm waste compost in growing media, International Journal of Agronomy, 10, 1-8.

Roy, S.J., Negrão, S. and Tester, M., 2014. Salt resistant crop plants. Curr. Opin. Biotechnol. 26, 115-124.

Salama, Y.A.M., Hassan, N.M.K., Saleh, S.A. and Zaki, M.F., 2012. Zinc amelioration effects on tomato growth and production under saline water irrigation conditions. Journal of Applied Science of Research, 8(12), 5877-5885.

SAS. 2006. Statistical Analysis System, SAS User's Guide Statistics. SAS Institute Inc. Editors, Cary, NC.

Savvas, D., Gianquinto, G., Tuzel, Y., Gruda, N., 2013. Soilless Culture, in good agricultural Practices for greenhouse vegetable cropsPrinciples for Mediterranean climate areas, ed. Baudoin, Non-Womdim, R. and Hodder, A., pp. 303-354.

Silva, A.B.F., Fernandes, P.D., Gheyi, H.R. and Blanco, F.F., 2008. Growth and yield of guava irrigated with saline water and addition of farmyard manure. Revista Brasileira de Ciências Agrárias, 3, 354-359.

Singh, J., Sastry, E.V.D. and Singh, V., 2012. Effect of salinity on tomato (Lycopersicon esculentum Mill.) during seed germination stage, Physiol. Mol. Biol. Plants, 18(1), 45-50.

Souto, A.G.L., Cavalcante, L.F., Gheyi, H.R., Nunes, J.C., Oliveira, F.I.F. and Oresca, D., 2015. Photosynthetic pigments and biomass in noni irrigated with saline waters with and without leaching. Rev. Bras. Engen. Agríc. Ambie. 19(11), 1035-1041.

Uddling, J., Gelang-Alfredsson, J., Piikki, K., Pleijel. H., 2007. Evaluating the relationship between leaf chlorophyll concentration and SPAD-502 chlorophyll meter readings. Photosynth. Res. 91, 37-46. 
Vaughn, S.F., Deppe, N.A., Palmquist, D.E. and Berhow, M.A. 2011. Extracted sweet corn tassels as a renewable alternative to peat in greenhouse substrates, Ind. Crops Prod. 33, 514-517.

Von Wettstein, D., 1957. Chlorophyll lethals and submicroscopic morphological changes in plasatids. Exp. Cell. Res., 12 (3), 427-506.
Wahome, P., Jesch, H. and Grittner, I. 2001. Mechanisms of salt stress tolerance in two rose rootstocks: Rosa chinensis "Major" and R. rubiginosa. Scientia Horticulturae, 87, 207-216.

Wang, Q., Chen, J. and Li, Y. 2004. Nondestructive and rapid estimation of leaf chlorophyll and nitrogen status of peace lily using a chlorophyll meter. J. Plant Nutr. 27, 557-569. 